\title{
Comparison of Intrauterine Device Insertion-Related Pain and Ease of Procedure at Different Times During Menstruation
}

\author{
Rahim İçi Araç Yerleştirilmesi ile Illişkili Ağrının ve İşlem Kolaylığının \\ Menstrüasyon Sırasında Farklı Zaman Dilimlerinde Karşılaştırılması
}

\author{
Meryem HOCAOGLU $\odot$, Taner GUNAY $\odot$, Ergul DEMIRCIVI BOR $\odot$, Ayse Gul NUR $\odot$, Abdulkadir TURGUT $\odot$, \\ Ates KARATEKE $\odot$
}

Ethics Committee Approval: This study was approved by Istanbul Medeniyet University Goztepe Training and Research Hospital Ethics Committee for Clinical Studies, 05 December 2017, 2017/0355.

Conflict of interest: The authors declare that they have no conflict of interest.

Funding: None.

Informed Consent: Informed consents were taken from the participants of the study.

\section{ABSTRACT}

Objective: Fear of pain during the copper intrauterine device (Cu-IUD) insertion may lead patients to reject this highly effective birth control method. The aim of this study was to investigate the pain scores associated with IUD insertion and the ease of procedure at different times during menstruation.

Method: In this prospective cohort trial, eligible women received IUD at three-time segments of menstruation: Group I, at 0.5 to 0.69-time segment ( $n=53)$; Group II, at 0.7 to 0.89-time segment $(n=67)$; and Group III, at 0.9 to 1 -time segment $(n=72)$. The time segments during menstruation were calculated for each participant by dividing the menstrual cycle day of IUD insertion to total number of menses days. The score of pain experienced at different steps of IUD insertion during and five min. after the procedure measured by Wong-Baker FACES Pain Rating Scale (WBS) and the ease of insertion were compared among groups.

Results: There were significant differences in age $(p=0.011)$ and time since the last delivery $(p=0.017)$. After adjusting for potential confounding factors, the mean WBS score and the ease of insertion were not statistically significant among groups, respectively $(p=0.664$ and $p=0.149)$. The most painful step was observed as uterine sounding (median, 4 [interquartile range \{IQR\}, 21). No significant correlation was observed between WBS scores, the ease of insertion, and main characteristics of the participants.

Conclusion: The most painful step of IUD insertion was observed as uterine sounding. IUD insertion-related pain and the ease of procedure do not appear to be different at any time in the second half of menstruation.

Keywords: IUD, contraception, copper, Wong-Baker FACES Pain Rating Scale, menstruation, pain

Öz

Amac: Bakırlı rahim içi araç (Cu-RíA) yerleștirilmesi sırasında oluşan ağrı korkusu, hastaların bu son derece etkili doğum kontrol yöntemini reddetmesine neden olabilir. Bu çalışmanın amacı, menstrüasyon sırasında farklı zaman dilimlerinde RiA yerleștirme ile ilișkili ağrı skorlarını ve ișlem kolaylığı araştırmaktı.

Yöntem: Bu prospektif kohort çalışmada, menstrüasyonun üç farklı zaman diliminde olmak üzere uygun kadınlara RiA yerleştirildi. Grup I menstrüasyonun 0,5-0,69'lik zaman diliminde ( $n=53)$, Grup II menstrüasyonun 0,7 to 0,89'lik zaman diliminde ( $n=67)$ ve Grup III ise menstrüasyonun 0,9 to 1 'lik $(n=72)$ zaman diliminde RIA yerlesstirilen katılımcilardan oluștu. Menstrüasyon sırasındaki zaman dilimleri her katılımcı için, RiA'nın yerleştirildiği menses gününün toplam menses günlerine bölünmesi ile hesaplandı. Farklı RiA yerleştirme aşamalarında ve RIA yerleştirildikten 5 dakika sonrasında hissedilen ağrı skoru Wong-Baker FACES Ağrı Derecelendirme Ölçeği kullanılarak ölçüldü. İşlem kolaylı̆̆ı gruplar arasında karşılaştırıldı.

Bulgular: Yaş $(p=0,011)$ ve son doğum üzerinden geçen süre $(p=0,017)$ ile ilişkili olarak gruplar arasında anlamlı fark saptandı. Potansiyel etki edici faktörler dıslandıktan sonra, ortalama WBS skoru ve RIA yerlestirme kolaylığı, gruplar arasında sırasıyla istatistiksel olarak anlamlı farklı değildi $(p=0,664, p=0,149)$. En ağrılı etabın histerometri yerleștirilmesi olduğu gözlendi (median, 4 [interquartile range $\{I Q R\}, 2])$. Katılımcıların WBS puanları, RiA yerleştirme kolaylığı ve temel karakteristik özellikleri arasında anlamlı bir ilișki gözlenmedi.

Sonuc: RiA yerleștirme sırasında en ağrılı etabın histerometri yerleştirilmesi olduğu gözlendi. Menstrüasyonun ikinci yarısında farklı zaman dilimlerinde RiA yerleştirilmesinin ağrı ve işlem kolayı̆ğı bakımından farklı olmadı̆̆ı görünmektedir.

Anahtar kelimeler: RiA, konstrasepsiyon, bakı, Wong-Baker FACES Ağrı Derecelendirme Ölçeği, menstrüasyon, ağrı

(c) Copyright Istanbul Medeniyet University Faculty of Medicine. This journal is published by Logos Medical Publishing.

Licenced by Creative Commons Attribution-NonCommercial 4.0 International (CC BY-NC 4.0)
Received: 19 April 2021

Accepted: 17 August 2021

Online First: 30 September 2021

Corresponding Author: M. Hocaoglu

ORCID: 0000-0002-1832-9993

Goztepe Prof Dr. Suleyman Yalcin

City Hospital, Department of

Obstetrics and Gynecology, Istanbul, Turkey

dr.meryemtaskiran@gmail.com

T. Gunay

ORCID: 0000-0002-3985-0702 E. Demircivi Bor ORCID: 0000-0002-4448-3863

A.G. Nur

ORCID: 0000-0003-0184-7644 Goztepe Prof. Dr. Suleyman Yalcin City Hospital, Department of Obstetrics and Gynecology, Istanbul, Turkey

A. Turgut ORCID: 0000-0002-3156-2116

A. Karateke

ORCID: 0000-0002-0199-6474

Istanbul Medeniyet University,

Department of Obstetrics and Gynecology, Faculty of Medicine, Istanbul, Turkey 


\section{INTRODUCTION}

Implantation of an intrauterine device (IUD) is one of the most common type of contraceptive method and used widely in the world ${ }^{1}$. The main concerns of the method are pain experienced during procedure, increased amount of menstrual blodd loss, expulsion of the device, and complications such as perforations.

Fear of pain during IUD insertion may lead patients to reject this highly effective birth control method $^{2}$. Factors that increase the risk of pain during implantation are increased age, being nulliparous, increased duration between the last menstruation or pregnancy and the procedure, not breastfeeding period, having dysmenorrhea, pain anticipation, and insertion of levonorgestrelreleasing intrauterine system (LNG-IUS) rather than copper IUD ${ }^{3}$. Extensive research has been published aiming to decrease the perception of pain during IUD insertion with no consensus on an effective method ${ }^{4,5}$.

The copper IUD may be inserted at any time during the menstrual cycle if pregnancy can be reasonably excluded ${ }^{6}$. IUD insertion during menses may be viewed as preferable by some providers, as it provides reassurance that the woman is not pregnant ${ }^{7}$. Theoretically, placing the device would be easier and less traumatic, thus generating less pain, as the cervical ostium is dilated slightly during menstrual bleeding period. In addition, insertion of the device would be more favorable during menstruation because it might decrease the bleeding duration as it is inserted during the endometrial breakdown ${ }^{8}$.

\section{Objectives}

There is no evidence that Cu-IUD insertion at different moments of the menstrual cycle influences pain during insertion ${ }^{7,8}$. Therefore, we decided to investigate pain scores associated with IUD insertion and ease of procedure at different times during menstruation.

\section{MATERIAL and METHODS}

\section{Statement of Ethics}

The study protocol was in accordance with the ethical guidelines and approval of Goztepe Prof Dr. Suleyman Yalcin City Hospital, Clinical Studies Ethic Committee (Protocol number 2017/0355). Informed consent was obtained from all participants in the study.

\section{Study design and participants}

The current study was a single-center, prospective cohort trial conducted from January 2019 through March 2020 at (Goztepe Prof. Dr. Suleyman Yalcin City Hospital). Women who applied to Family Planning Clinic and sought copper IUD insertion were clinically evaluated. The medical eligibility of the patients was based on WHO criteria?. Women whom have no contraindications for Cu-IUD insertion were invited to participate the present study. Eligible women were Caucasian, Turkish-speaking, aged 18-49 years, with previous menstrual cycle lengths of 24-34 days, and did not receive any analgesics in the $24 \mathrm{~h}$ prior to IUD insertion. Exclusion criteria were dysmenorrhea, dyspareunia, chronic pelvic pain, history of abnormal uterine bleeding, previous history of cervical surgery, presence of uterine abnormalities, endometrial lesions, adenomyosis, fibroids, intrauterine adhesions, patients who requested analgesia, and misplaced IUD (immediately after insertion).

Demographic and clinic characteristics, findings of the gynecological examination were recorded. In our clinic, IUD insertions are routinely performed during the second half of menses. Eligible women received IUD at three-time segments of menstruation: Group I, received IUD at 0.5 to 0.69-time segment; Group II, received IUD at 0.7 to 0.89-time segment; and Group III, received IUD at 0.9 to 1 -time segment. The time segments during menstruation were calculated for each participant by dividing the menstrual cycle day of IUD insertion to the total number of menses days. 
The primary outcome measure was the score of pain experienced at different steps of IUD insertion and five min. after the procedure, measured by the Wong-Baker FACES Pain Rating Scale (WBS). Secondary outcome was determined as the ease of IUD insertion. The ease of insertion was scored as easy, mildly difficult, moderately difficult, and very difficult.

\section{Procedure}

Participants were informed that data would be collected using a WBS. Pain medication was not given to the patients to reduce IUD placementrelated pain. The study provides IUDs or visits free of charge. Copper IUD (SMB $尺$ Copper $\mathrm{T}$ 380A, SMB Corporation of India, Mumbai) was inserted to all patients conforming to a standardized protocol. All insertions were applied while women were menstruating in the outpatient setting by two certified and experienced midwives (A.N. and A.I.). After pelvic examination, speculum was inserted into the vagina, and the cervix was cleansed with Povidone-iodine. The tenaculum was placed to the anterior lip of the cervix to stabilize the uterus and provide traction for straightening the cervical canal. Uterine sound was inserted for measurement of the uterine length. Then, the IUD was placed through the cervix using the cannula based on the measured cavity length. The cannula was released leaving IUD inside the uterine cavity and the threads were cut slightly short. Confirmation was done after placement by transvaginal ultrasound that the top of the IUD was at no smaller distance than $20 \mathrm{~mm}$ from the uterine fundus ${ }^{10}$.

A WBS was used in the evaluation of pain. This scale provides a score ranging from 0 , indicating "no pain," to 10 , indicating "maximum pain." 11 . Study staff were not blinded because a research assistant held on a sheet of paper showing the WBS in front of the patient asked her to rate the intensity of pain at seven steps during the IUD insertion: 1) Baseline (after placement in the dorsal supine position but before lithotomy positioning), 2) speculum placement, 3) tenaculum placement, 4) uterine sounding, 5) IUD insertion, 6) after speculum removal, 7) 5 min after speculum removal. Following IUD placement, the ease of insertion was recorded by two midwives who were applied all insertions (A.N. and A.I.).

\section{Follow-up}

Follow-up visit was scheduled one month after IUD insertion. As a part of the study protocol transvaginal ultrasound was performed to determine the position of IUD, at one month after placement by the same sonographer.

\section{Power calculation and statistical analyses}

A power analysis was performed for WBS pain scores during seven steps of IUD insertion by using the Univariate General Linear Model. The statistical power of this study was calculated as 0.979 (97.9\%).

Categorical variables were described through absolute frequencies, and continuous variables through median and interquartile range (IQR). Continuous variables were tested with the parametric test Shapiro-Wilk. The Kruskal-Wallis test and chi-square test were used to compare the demographic and clinic characteristics of the study subjects among the groups. The association between WBS pain scores during and five min after insertion and the timing of IUD insertion was assessed using the Kruskal-Wallis test. Potential confounding variables, including age and time since last delivery were controlled by using repeated measures ANOVA. Then, the association between WBS pain scores at procedural steps and timing of IUD insertion was evaluated. Moreover, multinomial logistic regression was used to assess the relationship between ease of procedure and timing of IUD insertion. In this analysis, potential confounding variables, including age and time since the last delivery were controlled. Pearson correlation and Mann Whitney-U test were used to investigate the relationship between WBS pain scores during and 
after insertion and some demographic and clinic characteristics of the participants.

\section{RESULTS}

A total of 192 women were included in the present study, 53 in Group I, 67 in group II, and 72 in Group III (Figure 1). All patients had successful IUD insertion and completed followup. There was no adverse event during the study period. After one month, during the transvaginal ultrasound, it was shown that all IUDs were correctly positioned in the uterine cavity. Moreover, there were significant differences in age $(p=0.011)$ and time since the last delivery $(p=0.017)$ between groups (Table 1$)$.

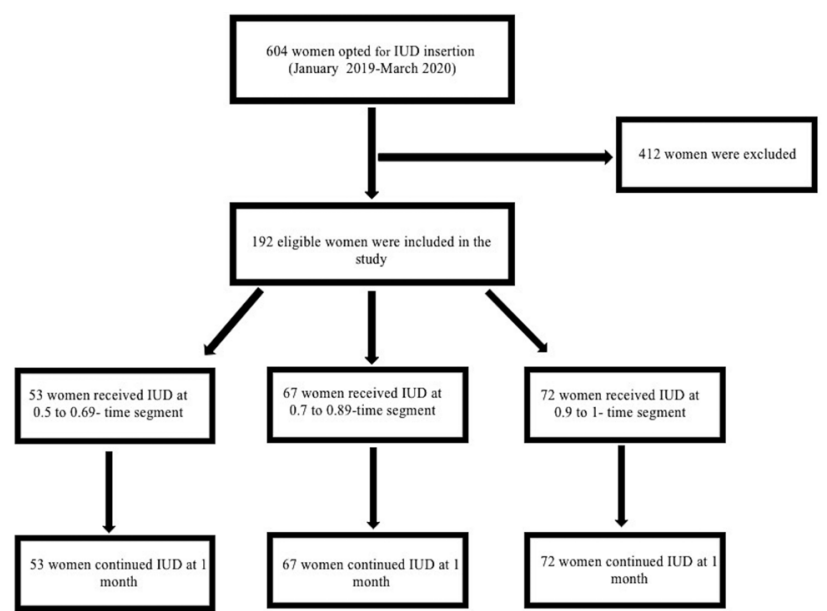

Figure 1. Flowchart of study subjects undergoing intrauterine device (IUD) insertion.

Table 1. Comparison of demographic and clinical characteristics between groups.

\begin{tabular}{|c|c|c|c|c|c|c|c|}
\hline Characteristics & $\begin{array}{r}\text { Gro } \\
0.5 \text { to } 0.69-\mathbf{t}^{-} \\
(\mathrm{n}=\end{array}$ & $\begin{array}{l}\text { up I } \\
\text { ime segment } \\
53 \text { ) }\end{array}$ & $\begin{array}{r}\text { Gro } \\
0.7 \text { to } 0.89-\mathbf{t} \\
(n=\end{array}$ & $\begin{array}{l}\text { up II } \\
\text { ime segment } \\
67 \text { ) }\end{array}$ & 0.9 to $\begin{array}{c}\text { Grou } \\
(\mathrm{n}-\mathrm{0}-\mathrm{ti} \\
(\mathrm{n}=\end{array}$ & $\begin{array}{l}\text { up III } \\
\text { ime segment } \\
=72 \text { ) }\end{array}$ & \\
\hline Quantitative $^{\S}$ & median (IQR) & $\min ; \max$ & median (IQR) & $\min ; \max$ & median (IQR) & min; $\max$ & $\mathbf{p}$ \\
\hline Age, years & $33(11)$ & $18-47$ & $34(10)$ & $22-47$ & $36.50(11)$ & $23-49$ & $0.011^{*}$ \\
\hline Body mass index, $\mathrm{kg} / \mathrm{m}^{2}$ & $25.67(7.50)$ & $16.89-42.97$ & $25.96(4.64)$ & $17.30-34.89$ & $25.87(5.80)$ & $17.78-39.45$ & 0.884 \\
\hline $\begin{array}{l}\text { Time since last delivery, } \\
\text { months }\end{array}$ & $24(113)$ & $2-288$ & $48(144)$ & $2-276$ & 108 (149) & $2-324$ & $0.017^{*}$ \\
\hline Qualitative & Frequency & $\%$ & Frequency & $\%$ & Frequency & $\%$ & p-value \\
\hline Number of vaginal deliveries & & & & & & & 0.338 \\
\hline 1 & 7 & 38.9 & 5 & 33.3 & 5 & 27.8 & \\
\hline 2 & 15 & 28.3 & 21 & 39.6 & 17 & 32.1 & \\
\hline$>2$ & 13 & 25.0 & 14 & 26.9 & 25 & 48.1 & \\
\hline Prior abortion & & & & & & & 0.278 \\
\hline No & 36 & 30.8 & 42 & 35.9 & 39 & 33.3 & \\
\hline Yes & 17 & 22.7 & 25 & 33.3 & 33 & 44.0 & \\
\hline Prior curettage & & & & & & & 0.113 \\
\hline No & 47 & 30.9 & 52 & 34.2 & 53 & 34.9 & \\
\hline Yes & 6 & 15.0 & 15 & 37.5 & 19 & 47.5 & \\
\hline Previous IUD insertion & & & & & & & 0.065 \\
\hline No & 23 & 37.1 & 22 & 35.5 & 17 & 27.4 & \\
\hline Yes & 30 & 23.1 & 45 & 34.6 & 55 & 42.3 & \\
\hline Type of delivery & & & & & & & 0.829 \\
\hline VD & 35 & 28.5 & 41 & 33.3 & 47 & 38.2 & \\
\hline CS & 18 & 26.1 & 26 & 37.7 & 25 & 36.2 & \\
\hline
\end{tabular}

Abbreviations: Min, minimum; Max, maximum; IQR, interquartile range; IUD, intrauterine device; VD, vaginal delivery; CS, cesarean delivery

The time segments during menstruation were calculated for each participant by dividing the menstrual cycle day of IUD insertion to total number of menses days.

${ }^{*} p<0.05$ indicates statistical significance.

${ }^{\S}$ Kruskal-Wallis test.

Chi-square test. 
Table 2. Main outcomes of the study.

\begin{tabular}{|c|c|c|c|c|c|c|c|}
\hline \multicolumn{8}{|c|}{$\begin{array}{c}\text { Primary outcomes: within-group variations in the median pain scores during and 5-minutes after IUD } \\
\text { insertion measured using a Wong-Baker FACES Pain Rating Scale }\end{array}$} \\
\hline \multirow[b]{2}{*}{ Procedural Step } & \multirow{2}{*}{\multicolumn{2}{|c|}{$\begin{array}{c}\text { Group I } \\
\begin{array}{c}0.5 \text { to } 0.69-\text {-time segment } \\
\text { of menstruation } \\
(n=53)\end{array} \\
\text { median (IQR) min; max }\end{array}$}} & \multirow{2}{*}{\multicolumn{2}{|c|}{$\begin{array}{l}\text { Group II } \\
0.7 \text { to } 0.89 \text {-time segment } \\
\text { of menstruation } \\
(\mathrm{n}=67)\end{array}$}} & \multicolumn{2}{|c|}{$\begin{array}{c}\text { Group III } \\
0.9 \text { to } 1.0 \text {-time segment } \\
\text { of menstruation } \\
(n=72)\end{array}$} & \multirow[b]{2}{*}{ p-value } \\
\hline & & & & & medi & min; max & \\
\hline Speculum placement & $2(2)$ & $0 ; 4$ & $2(2)$ & $0 ; 4$ & $2(0)$ & $0 ; 4$ & 0.620 \\
\hline Tenaculum placement & $4(2)$ & $2 ; 6$ & $2(2)$ & $0 ; 6$ & $4(2)$ & $2 ; 8$ & 0.445 \\
\hline Uterine sounding & $4(2)$ & $2 ; 8$ & $4(2)$ & $2 ; 8$ & $4(2)$ & $2 ; 8$ & 0.895 \\
\hline IUD insertion & $4(2)$ & $0 ; 8$ & $4(2)$ & $2 ; 10$ & $4(2)$ & $0 ; 6$ & 0.505 \\
\hline Speculum removal & $0(2)$ & $0 ; 4$ & $0(2)$ & $0 ; 6$ & $0(2)$ & $0 ; 4$ & 0.911 \\
\hline 5-minute after speculum removal & $0(0)$ & $0 ; 2$ & $0(0)$ & $0 ; 2$ & $0(0)$ & $0 ; 8$ & 0.248 \\
\hline Mildly difficult & & $.5 \%)$ & & $7.1 \%)$ & & $2.5 \%)$ & \\
\hline Moderately difficult & & $.6 \%)$ & & $.4 \%)$ & & (5\%) & \\
\hline
\end{tabular}

Abbreviations: Min, minimum; Max. maximum; IQR. interquartile range; IUD. intrauterine device

The time segments during menstruation were calculated for each participant by dividing the menstrual cycle day of IUD insertion to total number of menses days.

${ }^{*} p<0.05$ indicates statistical significance.

${ }^{\S}$ Kruskal-Wallis test.

Multinomial logistic regression.

For the primary outcome, the median WBS pain scores at the different stages of IUD insertion and five min after insertion are presented in Table 2. The median WBS score was not significantly different between the groups ( $>>0.05)$. Distributions of WBS score differences according

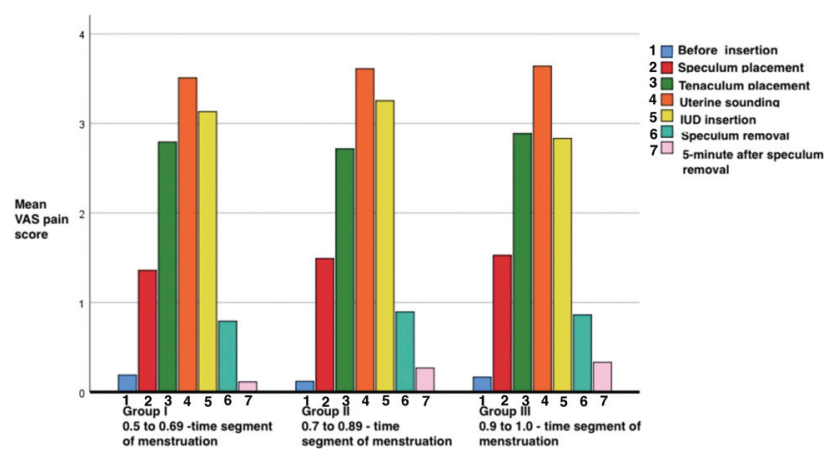

Figure 2. Distributions of Wong-Baker FACES Pain Rating Scale $(W B S)(0=$ no pain to $10=$ maximum pain) differences of the participants according to timing of IUD insertion. After adjustment for confounding variables, including age and time since last delivery, repeated measures ANOVA showed that the mean WBS score was not statistically significant among groups $(p=0.664)$. to timing of IUD insertion was obtained by using repeated measures ANOVA. After adjustment for potential confounding variables, including age and time since last delivery, the mean WBS score was not statistically significant among the groups ( $p=0.664$ ) (Figure 2 ). For the secondary outcome,

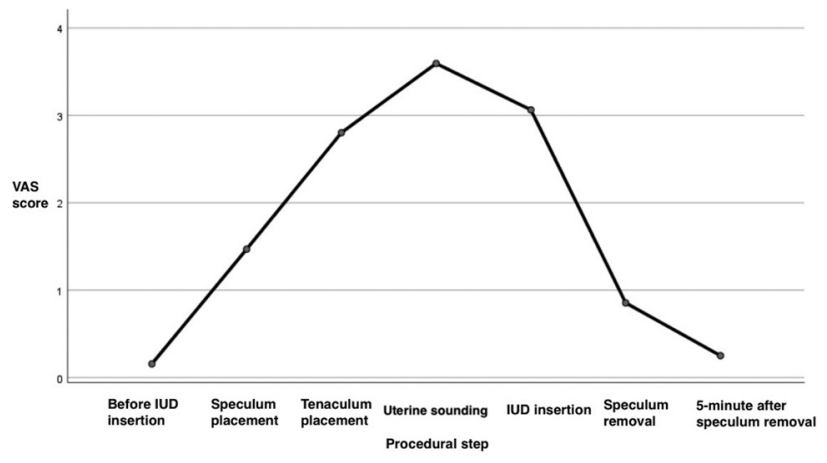

Figure 3. Differences in median Wong-Baker FACES Pain Rating Scale $(\mathrm{WBS})(0=$ no pain to $10=$ maximum pain) at each procedural step by using repeated measures ANOVA. Statistically significant difference was found in median WBS score among the study subjects $(p<0.001)$. While the most painful step was observed as uterine sounding (median, 4 [interquartile range $\{[Q R\}, 2]$ ), the least pain score was found immediately before the insertion (median, 0 [IQR, 0]). 
after adjustment for age and time since last delivery, the ease of IUD insertion was not significantly different among the groups $(p=0.149)$ (Table 2).

Figure 3 illustrates the differences in median WBS score at each procedural step differences between the participants. As a result, statistically significant difference was found in median WBS score among the study subjects $(p<0.001)$. While the most painful step was observed as uterine sounding (median, $4[\mathrm{IQR}, 2]$ ), the least pain score was found immediately before the insertion (median, 0 [IQR, 0]).

The validity was tested using Pearson's correlation coefficients between all median WBS pain scores and the demographic and clinical variables (age, time since last delivery, gravidity, parity, duration of menstrual period, and body mass index). As a result, no significant correlation was observed between WBS pain scores and above-mentioned characteristics of the participants $(p>0.05)$. Similarly, the chi-square test was used to evaluate correlations between ease of IUD insertion and the characteristics of the study subjects included mode of delivery and prior curettage. Finally, no significant correlation was found ( $p>0.05)$.

\section{DISCUSSION}

\section{Findings and interpretation}

In this prospective cohort trial, after adjustment for confounding variables, including age and time since the last delivery, we found no significant difference in median WBS pain scores and the ease of insertion among groups. While the most painful step was observed as uterine sounding, the least pain score was found immediately before the insertion. Moreover, no significant correlation was observed between WBS pain scores, the ease of insertion and the main characteristics of the participants.

\section{Similarities and differences in relation to other studies}

AlthoughIUDsare the highest ranked contraceptive methods in terms of efficacy, a substantial amount of women and medical doctors are known not to prefer using the device due to its painful insertion procedure $^{12}$. Various adjunctive measures for reduction of IUD insertion-related pain were studied $^{13}$. A recent systematic review and network meta-analysis that synthesized the evidence about the pharmacologic treatment for pain management of IUD insertion showed that the most powerful pain reliever was lidocaine-prilocaine cream ${ }^{12}$. Furthermore, non-pharmacological pain management strategies include psychological preparation and counselling before insertion and verbal anesthesia and distraction during the insertion might reduce pain levels ${ }^{14}$. In the review, many authors suggested that further studies focusing on non-pharmacological interventions needed to be conducted and reported in the literature ${ }^{13}$. In this context, we aimed to investigate pain related to IUD insertion and the ease of insertion at different times during menstruation without analgesic use. Our data showed no significant difference in median WBS pain scores and the ease of IUD insertion between groups. Therefore, it may be assumed that Cu-IUD might be inserted at any time segment in the second half of the menstruation regarding perceived pain, as well as ease of insertion.

No published studies has yet demonstrated that Cu-IUD insertion at different time segments of the menses influences pain related to IUD insertion. However, reviewing the literature, we found relatively few studies that have focused on painrelated to IUD insertion within menses or outside menses without pain medication. Kokonya et al. determined the insertion problems including pain related to an IUD insertion during or outside menses. This study comprised 1667 women and showed that pain at the time of Cu-IUD insertion was more common among those who had a Cu-IUD inserted outside menses than during 
menses. However, they did not report direct statistical comparisons regarding the pain measurement ${ }^{15}$. Another study by van der Heijden et al. performed a randomized controlled trial to compare pain perception for the insertion of the levonorgestrel-releasing intrauterine system (LNG-IUS) during menstruation and outside menstruation. They did not find a difference in patient-perceived pain between the groups, stratified for nulliparous and multiparous women ${ }^{8}$. In the other hand, a prospective study in 84 nulliparous women evaluated the expected, immediate, and three-minute pain response following IUD insertion undergoing a first IUD insertion. The authors suggested that immediate pain following IUD insertion was independent of day of cycle $^{16}$.

Notably, we found that the most painful step was uterine sounding. In consistent with our results, in a prospective, randomized, controlled, and triple blinded study assessing the effect of eutectic mixture of local anesthetics on IUD insertion pain, the authors suggested that insertion hysterometry was found as the most painful IUD insertion ${ }^{17}$. However, the insertion instructions recommend performing uterine sounding prior to IUD insertion to guarantee proper determination of uterine size and position ${ }^{18,19}$. In this context, Ali et al. ${ }^{19}$ suggested that $\mathrm{Cu}$-IUD can be inserted successfully without using uterine sound provided using TV/ US prior to insertion in a randomized clinical trial. They concluded that this method related to less pain and greater women satisfaction during insertion with shorter duration.

\section{Strength and weaknesses}

The present investigation had the following strengths. Our study has an adequate sample size. All participants used the same type of IUD. We used a standard WBS to measure pain, as it is the most reliable pain measurement tool, and a standardized insertion that involved all steps of IUD insertion. All placements were performed electively. Furthermore, all IUDs were inserted by two specialized midwives, limiting variability in skill among providers. However, this study has a limitation too. It was monocentric.

\section{Open questions and future research}

The need for further studies examining adequate and reliable pain relief with IUD insertion is evident $^{20}$. However, non-pharmacological pain management strategies include timing of IUD insertion might ease to reduce pain levels. IUD insertion during menses may be viewed as preferable by some providers ${ }^{7}$. Currently, many clinicians prefer to do the IUD insertion during or toward the end of a woman's menstrual period to minimize the complaints of bleeding which usually accompany insertion. Therefore, our study was designed to explore whether anticipated pain during IUD placement can be affected by different times at the second half of the menstruation. We suggest further studies to confirm and extend our findings. Furthermore, it would be great interest to explore the effects of inserting IUDs at different times during menstruation on contraceptive continuation, effectiveness, and safety.

\section{CONCLUSION}

To the best of our knowledge, this is the first study to assess the pain scores during and after IUD insertion and the ease of procedure at different times during menstruation. Our findings revealed that the ease of insertion and the level of pain perceived at any time in the second half of menstruation did not appear to be different. Moreover, the most painful step of IUD insertion was observed as uterine sounding. We suggest further studies to confirm and extend our findings.

\section{REFERENCES}

1. Dilbaz B, Şengül Ö. Laparoscopic removal of extrauterine intrauterine device found in the broad ligament: A case report. Göztepe Tip Dergisi. 2013;28:233-5.

Available from: https://jag.journalagent.com/medeniyet/ 
pdfs/MEDJ_28_4_233_235.pdf

2. Karabayirli S, Ayrim AA, Muslu B. Comparison of the analgesic effects of oral tramadol and naproxen sodium on pain relief during IUD insertion. J Minim Invasive Gynecol. 2012;19:581-4. [CrossRef]

3. Allen RH, Carey MS, Raker C, Matteson K. A prospective cohort study of pain with intrauterine device insertion among women with and without vaginal deliveries. J Obstet Gynaecol. 2014;34:263-7. [CrossRef]

4. Abdellah MS, Abbas AM, Hegazy AM, El-Nashar IM. Vaginal misoprostol prior to intrauterine device insertion in women delivered only by elective cesarean section: a randomized double-blind clinical trial. Contraception. 2017;95:538-43. [CrossRef]

5. Lopez LM, Bernholc A, Zeng Y, et al. Interventions for pain with intrauterine device insertion. Cochrane Database Syst Rev. 2015:CD007373. [CrossRef]

6. Curtis KM, Tepper NK, Jatlaoui TC, et al. United States Medical Eligibility Criteria for Contraceptive Use, 2016. MMWR Recomm Rep. 2016;65:1-104. [CrossRef]

7. Whiteman MK, Tyler CP, Folger SG, Gaffield ME, Curtis $\mathrm{KM}$. When can a woman have an intrauterine device inserted? A systematic review. Contraception. 2013;87:666-73. [CrossRef]

8. van der Heijden P, Geomini P, Herman MC, Veersema S, Bongers MY. Timing of insertion of levonorgestrelreleasing intrauterine system: a randomised controlled trial. BJOG. 2017;124:299-305. [CrossRef]

9. WHO. Medical eligibility criteria for contraceptive use. $5^{\text {th }}$ ed. Available from: http://apps.who.int/iris/bitstream/ha ndle/10665/181468/9789241549158_eng.pdf;jsessioni $\mathrm{d}=$ FDDBFF265AA2E8EC3616D73DB88A8B69?sequence $=1$

10. Tsikouras P, Vrachnis N, Grapsa A, et al. IUD in firsttrimester abortion: immediate intrauterine contraceptive devices insertion vs delayed insertion following the next menstruation bleeding. Arch Gynecol Obstet. 2014;290:99-105. [CrossRef]

11. Lukes AS, Roy KH, Presthus JB, Diamond MP, Berman JM, Konsker KA. Randomized comparative trial of cervical block protocols for pain management during hysteroscopic removal of polyps and myomas. Int J Womens Health. 2015;7:833-9. [CrossRef]
12. Samy A, Abbas AM, Mahmoud M, et al. Evaluating different pain lowering medications during intrauterine device insertion: a systematic review and network metaanalysis. Fertil Steril. 2019;111:553-61.e4. [CrossRef]

13. American College of Obstetricians and Gynecologists' Committee on Gynecologic Practice; Long-Acting Reversible Contraceptive Expert Work Group. Committee Opinion No 672: Clinical Challenges of Long-Acting Reversible Contraceptive Methods. Obstet Gynecol. 2016;128:e69-77. [CrossRef]

14. Gemzell-Danielsson K, Mansour D, Fiala C, Kaunitz AM, Bahamondes L. Management of pain associated with the insertion of intrauterine contraceptives. Hum Reprod Update. 2013;19:419-27. [CrossRef]

15. Kokonya DA, Sinei SK, Sekadde-Kigondu CB, Morrison CS, Kwok C, Weiner DH. Experience with IUCD insertion outside of menses in Kenya. East Afr Med J. 2000;77:36973. [CrossRef]

16. Goldstuck ND, Matthews ML. A comparison of the actual and expected pain response following insertion of an intrauterine contraceptive device. Clin Reprod Fertil. 1985;3:65-71. PMID: 3978537.

17. Tavakolian S, Doulabi MA, Baghban AA, Mortazavi A, Ghorbani $M$. Lidocaine-prilocaine cream as analgesia for IUD insertion: a prospective, randomized, controlled, triple blinded study. Glob J Health Sci. 2015;7:399-404. [CrossRef]

18. Ngo LL, Ward KK, Mody SK. Ketorolac for pain control with intrauterine device placement: a randomized controlled trial. Obstet Gynecol. 2015;126:29-36. [CrossRef]

19. Ali MK, Abbas AM, Abdalmageed OS, Farghaly TA, Yosef $\mathrm{AH}$. Classic versus uterine sound-sparing approach for insertion of copper T380A intrauterine device: A randomized clinical trial. Middle East Fertil Soc J. 2018;23:211-5. [CrossRef]

20. Conti JA, Lerma K, Schneyer RJ, Hastings CV, Blumenthal PD, Shaw KA. Self-administered vaginal lidocaine gel for pain management with intrauterine device insertion: a blinded, randomized controlled trial. Am J Obstet Gynecol. 2019;220:177.e1-177.e7. [CrossRef] 